\title{
Nutritional Endosymbiotic Systems in Plants: Bacteria Function like 'Quasi- Organelles' to Convert Atmospheric Nitrogen into Plant Nutrients
}

\author{
James F White $\mathrm{Jr}^{1 *}$, Holly Johnson ${ }^{2}$, Mónica S Torres ${ }^{1}$ and Ivelisse Irizarry ${ }^{1}$
}

${ }^{1}$ Department of Plant Biology and Pathology, Rutgers University, New Brunswick, New Jersey, USA

${ }^{2}$ Department of Engineering Technologies, Safety and Construction, Central Washington University, Ellensburg, Washington, USA

We propose that most plants are inhabited by nitrogen-fixing endosymbiotic bacteria whose hosts eventually degrade them through oxidation to extract nitrogen-containing nutrients. Such bacteria comprise the 'nutritional endosymbiotic systems' of plants thus enabling them to obtain critical nutrients for growth and development. It is already well known that endophytic microbes, both prokaryotic and eukaryotic, systemically inhabit plants [1-6]. Numerous studies of the diversity of endophytic microbes in plants suggest that these microbes are diverse enough and occur in high enough numbers as to constitute communities $[4,7,8]$. The number of microbes in plants further suggests that they may be biologically important to plant functions. However, we still know little about the roles that endophytic microbes play in enabling plant growth and development. Several hypotheses, all of which are based on supportive evidence, have been proposed that pose functional ecological roles for endophytes. These hypotheses include, but are not limited to, the following: defensive mutualism; plant growth promotion; stress protection; oxidative stress protection; habitat adaptation; and associative nitrogen fixation [1,2,919]. But, none of these hypotheses provide a sufficient mechanistic understanding of how endosymbiotic microbes benefit their host plants.

One critical function about which there is a dearth of mechanistic knowledge is the role which microbial endosymbionts play in aiding plants to acquire nutrients. Acquisition of nutrients, particularly nitrogen, is critical for plants to grow and develop. Moreover, its presence is frequently limited in soils. Plants are, however, immersed constantly in nitrogen gas $\left(\mathrm{N}_{2}\right)$ since the earth's atmosphere consists of approximately $79 \% \mathrm{~N}_{2}$. But, plants cannot access the abundant atmospheric $\mathrm{N}_{2}$ because they lack nitrogenase enzyme systems in their genomes. Nitrogen is so critical to plant life and so abundant in the atmosphere that it is astonishing that plants did not evolve their own nitrogenases, as bacteria have. With regard to plant acquisition of nitrogen, the current and widely held belief is that non-rhizobial plants must absorb nitrogen from soils. This belief has been held so universally and for such a long time that one might consider it to be a 'central dogma' of plant ecology [20]. Yet, many plants (e.g., desert cacti and agaves, and epiphytic orchids, epiphytic ferns and epiphytic bromeliads) grow in circumstances (e.g. low water, low nutrient environments) where they cannot absorb nitrates from soils, and yet they manage to thrive $[21,22]$. We propose that exceptions, like the above-mentioned plants, demonstrate that the accepted model of nitrogen absorption predominantly from soils is not correct. We also posit that plants have not evolved their own nitrogenases because they already possess nutritional endosymbiotic systems involving nitrogen-fixing proteobacteria that function as 'quasi-organelles' to provide them with critical forms of nitrogenous compounds $[1,12,23]$. We further hypothesize that many plants obtain the majority of the nitrogen they require from endosymbiotic microbes and only a portion from soil nitrates.

Recently, we published evidence that certain grasses possess the capacity to extract nutrients from symbiotic nitrogen-fixing proteobacteria through a process of oxidation [24]. We termed this processas 'OxidativeNitrogenScavenging'(ONS).Paungfoo-Lonhienne et al. [25] presented evidence that some plants appear to phagocytize bacteria as a nutrient source. We have additional unpublished data that many additional plant species possess ONS systems involving intracellular proteobacteria that are digested/oxidized in the process of plant development (Figure 1). The endosymbiotic bacteria that we encountered in plants are seed-transmitted and robust, in that they survive periods of seed storage. It is logical that these microbes are part of the nutritional endosymbiotic systems employed by plants. Likely, these systems provide developing plants with oligopeptides, amino acids, vitamins, nucleic acids, that not only contain nitrogen but that may serve as the building blocks of essential plant molecules. It is likely that all plants may obtain some nutrients directly from microbes at some point in plant development.

Nutritional endosymbiotic systems have been largely unstudied partly because the presence of the endosymbiotic microbes in healthy plants has gone unnoticed due to their small sizes. Further, many of the microbes involved are not easily cultured. It is also frequently

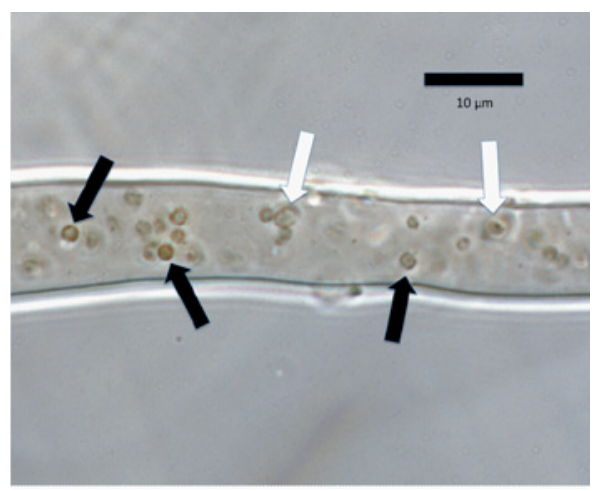

Figure 1: Oxidizing bacteria (Pantoea sp.; arrows) within a root hair cell of a seedling of rapeseed (Brassica napus), showing bacterial cells in vesicles surrounded by red-staining $\mathrm{H}_{2} \mathrm{O}_{2}$ (arrows; stained with 3,3'-Diaminobenzidine/ horseradish peroxidase then counterstained with $0.1 \%$ aniline blue/lactic acid). Later stages of oxidation are indicated with white arrows.

*Corresponding author: James F White Jr, Department of Plant Biology and Pathology, Rutgers University, New Brunswick, New Jersey, USA, E-mail: white@aesop.rutgers.edu, jwhite3728@gmail.com

Received November 18, 2012; Accepted November 21, 2012; Published November 26, 2012

Citation: White Jr JF, Johnson H, Torres MS, Irizarry I (2012) Nutritional Endosymbiotic Systems in Plants: Bacteria Function like 'Quasi-Organelles' to Convert Atmospheric Nitrogen into Plant Nutrients. J Plant Pathol Microb 3:e104. doi:10.4172/2157-7471.1000e104

Copyright: (c) 2012 White Jr JF, et al. This is an open-access article distributed under the terms of the Creative Commons Attribution License, which permits unrestricted use, distribution, and reproduction in any medium, provided the original author and source are credited. 
Citation: White Jr JF, Johnson H, Torres MS, Irizarry I (2012) Nutritional Endosymbiotic Systems in Plants: Bacteria Function like 'Quasi-Organelles' to Convert Atmospheric Nitrogen into Plant Nutrients. J Plant Pathol Microb 3:e104. doi:10.4172/2157-7471.1000e104

difficult to identify plants that are free of the proteobacteria in order to conduct controlled experiments. The challenge to biologists studying these systems is to design studies to measure the extent to which plants obtain nutrients through digestion/oxidation of endosymbiotic microbes and to identify precisely what nutrients plants obtain from the microbes. Gaining an understanding of the nutritional functions of endosymbiotic microbes in enabling plant growth and development will change our understanding of how microbes and plants interact, how nitrogen flows in ecosystems and how plants have evolved.

\section{Acknowledgements}

We are grateful to the New Jersey Agricultural Experiment Station, the Rutgers University Turf Science Center, and Central Washington University for resources and financial support.

\section{References}

1. Döebereiner J (1992) History and new perspectives of diazotrophs in association with non-leguminous plants. Symbiosis 13: 1-3.

2. James EK (2000) Nitrogen fixation in endophytic and associative symbiosis. Field Crops Research 65: 197-209.

3. Álvarez-Loayza P, White JF Jr, Torres MS, Balslev H, Kristiansen T, et al. (2011) Light converts endosymbiotic fungus to pathogen, influencing seedling survival and niche-space filling of a common tropical tree, Iriartea deltoidea. PLoS ONE 6: e16386.

4. Arnold AE, Lutzoni F (2007) Diversity and host range of foliar fungal endophytes: are tropical leaves biodiversity hotspots? Ecology 88: 541-549.

5. Bacon CW, Hinton DM (2011) In planta reduction of maize seedling stalk lesions by the bacterial endophyte Bacillus mojavensis. Can J Microbiol 57: 485-492.

6. Stone JK, Bacon CW, White JF Jr (2000) An overview of endophytic microbes. Marcel-Dekker, New York, USA 3-30.

7. Fürnkranz M, Lukesch B, Müller H, Huss H, Grube M, et al. (2012) Microbial diversity inside pumpkins: microhabitat-specific communities display a high antagonistic potential against phytophathogens. Microb Ecol 63: 418-428.

8. Taulé C, Mareque C, Barlocco C, Hackembruch F, Reis VM, et al. (2012) The contribution of nitrogen fixation to sugarcane (Saccharum officinarum L.), and the identification and characterization of part of the associated diazotrophic bacterial community. Plant Soil 356: 35-49.

9. Clay K (1988) Fungal endophytes of grasses: a defensive mutualism between plants and fungi. Ecology 69: 10-16.

10. Clay K, Holah J, Rudgers JA (2005) Herbivores cause a rapid increase in hereditary symbiosis and alter plant community composition. PNAS 102 12465-12470.

11. Glick BR (1995) The enhancement of plant growth by free-living bacteria. Can J Microbiol 41: 109-117.

12. James EK, Reis VM, Olivares FL, Baldani JI, Dobereiner J (1994) Infection of sugar cane by the nitrogen-fixing bacterium Acetobacter diazotrophicus. J Exp Bot 45: 757-766.

13. Kloepper JW (1994) Plant growth-promoting rhizobacteria (other systems). In: Okon Y (ed.) Azospirillum/Plant Associations, CRC Press, Inc., Boca Raton, FL, USA, 137-166.

14. Kuldau G, Bacon C (2008) Clavicipitaceous endophytes: Their ability to enhance resistance of grasses to multiple stresses. Biological Control 46: 57 71.

15. Malinowski M, Belesky DP, Lewis GC (2005) Abiotic stresses in endophytic grasses. Blackwell Publishing, Ames, IA, USA 187-199.

16. Redman RS, Sheehan KB, Stout RG, Rodriguez RJ, Henson JM (2002) Thermotolerance generated by plant/fungal symbiosis. Science 298: 1581.

17. Rodriguez RJ, Woodward C, Kim YO, Redman RS (2009) Habitat-adapted symbiosis as a defense against abiotic and biotic stresses. CRC Press, Boca Raton, FL., USA 335-346.
18. Torres MS, White Jr JF, Zhang X, Hinton DM, Bacon CW (2012) Endophytemediated adjustments in host morphology and physiology and effects on host fitness traits in grasses. Fungal Ecology 5: 322-330.

19. White JF Jr, Torres MS (2010) Is plant endophyte-mediated defensive mutualism the result of oxidative stress protection? Physiol Plant 138: 440-446.

20. Chapin III FS, Matson PA, Mooney HA (2002) Principles of Terrestrial Ecosystem Ecology. Springer, New York 1-398.

21. Puente ME, Bashan Y (1994) The desert epiphyte Tillandsia recurvata harbours the nitrogen-fixing bacterium Pseudomonas stutzeri. Can J Bot 72: 406-408.

22. Tsavkelova EA, Cherdyntseva TA, Netrusov Al (2004) Bacteria associated with the roots of epiphytic orchids. Mikrobiologiia 73: 825-831.

23. Reinhold-Hurek B, Hurek T (2011) Living inside plants: bacterial endophytes. Curr Opin Plant Biol 14: 435-443.

24. White JF Jr, Crawford H, Torres MS, Mattera R, Irizarry I, et al. (2012) A proposed mechanism for nitrogen acquisition by grass seedlings through oxidation of symbiotic bacteria. Symbiosis 57: 161-171.

25. Paungfoo-Lonhienne C, Rentsch D, Robatzek S, Webb RI, Sagulenko E, et al (2010) Turning the table: plants consume microbes as a source of nutrients. PLoS One 5: e11915. 